\title{
Seasonal cycle and modal structure of particle number size distribution at Dome C, Antarctica
}

\author{
E. Järvinen ${ }^{1}$, A. Virkkula ${ }^{1,2}$, T. Nieminen ${ }^{1}$, P. P. Aalto ${ }^{1}$, E. Asmi ${ }^{2}$, C. Lanconelli ${ }^{3}$, M. Busetto ${ }^{3}$, A. Lupi ${ }^{3}$, R. Schioppo ${ }^{4}$, \\ V. Vitale ${ }^{3}$, M. Mazzola ${ }^{3}$, T. Petäjä ${ }^{1}$, V.-M.Kerminen ${ }^{1}$, and M. Kulmala ${ }^{1}$ \\ ${ }^{1}$ University of Helsinki, Department of Physics, P.O. Box 64, 00014 Univ. of Helsinki, Finland \\ ${ }^{2}$ Finnish Meteorological Institute, P.O. Box 503, 00560 Helsinki, Finland \\ ${ }^{3}$ Institute of Atmospheric Sciences and Climate of the Italian National Research Council (ISAC-CNR), Via Gobetti, 101, \\ 40129 Bologna, Italy \\ ${ }^{4}$ ENEA-UTA Unità Tecnica Antartica, via Anguillarese 301, S.Maria di Galliera, Rome, Italy
}

Correspondence to: E. Järvinen (emma.jarvinen@helsinki.fi)

Received: 25 January 2013 - Published in Atmos. Chem. Phys. Discuss.: 4 March 2013

Revised: 19 June 2013 - Accepted: 24 June 2013 - Published: 5 August 2013

\begin{abstract}
We studied new particle formation and modal behavior of ultrafine aerosol particles on the high East Antarctic plateau at the Concordia station, Dome $\mathrm{C}\left(75^{\circ} 06^{\prime} \mathrm{S}\right.$, $\left.123^{\circ} 23^{\prime} \mathrm{E}\right)$. Aerosol particle number size distributions were measured in the size range $10-600 \mathrm{~nm}$ from 14 December 2007 to 7 November 2009. We used an automatic algorithm for fitting up to three modes to the size distribution data. The total particle number concentration was low with the median of $109 \mathrm{~cm}^{-3}$. There was a clear seasonal cycle in the total particle number and the volume concentrations. The concentrations were at their highest during the austral summer with the median values of $260 \mathrm{~cm}^{-3}$ and $0.086 \mu \mathrm{m}^{3} \mathrm{~cm}^{-3}$, and at their lowest during the austral winter with corresponding values of $15 \mathrm{~cm}^{-3}$ and $0.009 \mu^{3} \mathrm{~cm}^{-3}$. New particle formation events were determined from the size distribution data. During the measurement period, natural new particle formation was observed on 60 days and for 15 of these days the particle growth rates from 10 to $25 \mathrm{~nm}$ in size could be determined. The median particle growth rate during all these events was $2.5 \mathrm{~nm} \mathrm{~h}^{-1}$ and the median formation rate of $10 \mathrm{~nm}$ particles was $0.023 \mathrm{~cm}^{-3} \mathrm{~s}^{-1}$. Most of the events were similar to those observed at other continental locations, yet also some variability in event types was observed. Exceptional features in Dome $\mathrm{C}$ were the winter events that occurred during dark periods, as well as the events for which the growth could be followed during several consecutive days. We called these latter events slowly growing events. This paper is the first one to analyze long-term size distribution data from Dome
\end{abstract}

$\mathrm{C}$, and also the first paper to show that new particle formation events occur in central Antarctica.

\section{Introduction}

The climatic effects of atmospheric aerosol particles are tied strongly with their concentration, size distribution, chemical composition and dynamical behaviour in the atmosphere (Forster et al., 2007; Quaas et al., 2009; Ghan et al., 2012). A key process in this respect is atmospheric new particle formation, including nucleation from precursor gases and subsequent growth of nucleated clusters to larger sizes (Kulmala et al., 2004; Wang and Penner, 2009; Kazil et al., 2010; Makkonen et al., 2012). The formation rate of new aerosol particles is linked closely with the gaseous sulfuric acid concentration (e.g. Kulmala et al., 2006; Petäjä et al., 2009; Kerminen et al., 2010; Sipilä et al., 2010), which is related to sulfur dioxide originating mostly from anthropogenic sources.

The concentrations of anthropogenic aerosols have increased markedly since pre-industrial times, while at the same time the concentrations of natural aerosols have remained at roughly the same level (Charlson and Wigley, 1994). Antarctica is an ideal place for studying the natural aerosol processes, since it is the continent furthest away from anthropogenic pollution sources. There is practically no vegetation, and the oceans surrounding the continent are the main source of aerosol particles (e.g., Shaw, 1988; O’Dowd 
et al., 1997; Asmi et al., 2010; Yu and Luo, 2010; Udisti et al., 2012), even though some long-range transported pollutant aerosols from other continents have been observed (e.g., Fiebig et al., 2009). Studying new particle formation events in the Antarctica gives us information on natural aerosol processes and how natural processes affect the formation rate of new aerosol particles.

Aerosol number concentrations, size distributions and chemical composition have been studied at several stations around Antarctica, and long-term records of particle number concentrations have been reported, e.g. from Neumayer (Weller et al., 2011) and the South Pole (e.g., Samson, 1990). Particle number size distributions have been measured mainly during campaigns at coastal stations (e.g., Ito, 1993; Koponen et al., 2003; Virkkula et al., 2007; Asmi et al., 2010; Pant et al., 2011; Belosi et al., 2012) and on the upper plateau at the South Pole (e.g., Park et al., 2004). Hara et al. (2011) presented number size distributions and aerosol volatility measured at the Japanese Antarctic station Syowa, on the coast of Queen Maud Land in 2003-2005. Norwegian researchers recently started long-term size distribution measurements at the Troll station, more to the inland of Queen Maud Land (Hansen et al., 2009), but there are no long-term size distribution measurements from the upper plateau. The measurements presented here are the first step towards filling in this gap: particle number size distributions have been measured at the Concordia station at Dome $\mathrm{C}$ on the upper plateau of East Antarctica since December 2007.

New particle formation has been observed at several stations in coastal Antarctica (Ito, 1993; Koponen et al., 2003; Asmi et al., 2010). The motivation of this study was to observe and analyse new particle formation events in the inland Antarctica. In this work we will present seasonal variation of the particle number and volume concentration and modal structure of particle number size distributions, as well as analyses of new particle formation events during the first continuous period from December 2007 until November 2009.

\section{Instrumentation and data analysis methods}

\subsection{Size distribution measurements}

We measured particle number size distributions at the Italian-French Concordia station at Dome C $\left(75^{\circ} 06^{\prime} \mathrm{S}\right.$, $123^{\circ} 23^{\prime} \mathrm{E}$ ). The station is located on the upper plateau of East Antarctica at $3200 \mathrm{~m}$ above sea level and $1100 \mathrm{~km}$ away from the nearest coast. The measurement period was from 14 December 2007 to 7 November 2009.

The sampling site is the same as was used by Udisti et al. (2012) and Becagli et al. (2012) for taking filter samples for chemical analyses. This sampling site is located about $1 \mathrm{~km}$ southwest of the station main buildings, upwind in the direction of the prevailing wind. All motorized activity is for- bidden south and within $300 \mathrm{~m}$ north of the sampling site (Udisti et al., 2012). The northeastern direction was declared as the contaminated sector $\left(10-90^{\circ}\right)$ due to diesel generator and motor vehicle emissions at the station. Consequently, the data were omitted from further analysis when the measured winds were from the contaminated sector. Due to contamination, 6.6 percent of the measured data were removed from the analysis.

Snow mobiles and other traffic were active from early November to February and thus did not create major gaps to the winter measurements. However, there are minor gaps in the measured data due to power failures. Longer gaps in the data exist for the early spring 2008 and for winter 2009.

Particle number size distributions in the size range 10$600 \mathrm{~nm}$ were measured with a Differential Mobility Particle Sizer (DMPS) that consisted of a Hauke-type medium-size DMA (Winklmayr et al., 1991) in a closed-loop arrangement and a TSI Model 3010 condensation particle counter (CPC) that detects particles larger than $10 \mathrm{~nm}$. The DMPS setup was similar to that used at Aboa by Virkkula et al. (2007). The time resolution of the raw data was $10 \mathrm{~min}$. The size distribution data in this study are presented in the UTC time but the new particle formation plots are presented in local time (UTC $+8 \mathrm{~h})$.

In an ideal setup, there would be an independent CPC for measuring total particle number concentrations and a DMPS from which the total number concentration can be calculated. The agreement of these two would increase the quality of the data. However, in the measurements discussed here there was no additional CPC available, so we cannot calculate the degree of closure between two independent measurement methods.

\subsection{Data processing methods}

\subsubsection{Mode fitting}

Log-normal modes were identified from the size distributions with an automatic algorithm (Hussein et al., 2005). This algorithm parameterizes aerosol particle number size distributions with a multi log-normal distribution function. The multi log-normal distribution function is widely in use to parameterize atmospheric aerosol particle size distributions. The algorithm used did not need a user decision for the initial input parameters, only the maximum number of fitted modes was set to be three, which is typically enough to represent atmospheric aerosol size distributions. The algorithm works by reducing the maximum number of possible modes with an overlapping test between adjacent modes. The quality of the log-normal fit is based on least-squares value between the fitted and measured size distribution. The modes found by the algorithm were numbered according to diameter from the smallest to the largest. The diameter of the fitted modes depended solely on the size distribution data. The term fitted 
modes is used when referring to the modes obtained by the algorithm.

Later in this work the terms nucleation mode, Aitken mode and accumulation mode ranges refer to the measured data in pre-selected size ranges: nucleation mode range $(<25 \mathrm{~nm})$, Aitken mode range $(25-100 \mathrm{~nm})$ and accumulation mode range ( $>100 \mathrm{~nm})($ Dal Maso et al., 2005).

\subsubsection{New particle formation event classification}

New particle formation event days - simply event days below - were determined following the procedure introduced by Dal Maso et al. (2005). We counted as an event day those days when growth of the newly formed particles could be reliably followed as well the days when growth was clearly detected but could not be followed due to for example changes in the air masses. We divided the event days into class 1 events and into class 2 events. From a class 1 event, we could determine the growth rate in contrast to class 2 events. Furthermore we divided the class 1 events into normal events that remind events typically observed at continental sites (for example in Hyytiälä, Finland, e.g. Dal Maso et al., 2005) and into slowly growing events, when the growth could be followed for several days.

Event days were carefully checked to verify that the observed events were natural events and not due to contamination from the station. For this reason, the wind direction and speed were tracked two days before the event started. If the wind direction was from the polluted sector or the wind speed was lower than $2 \mathrm{~m} \mathrm{~s}^{-1}$ for more than one hour during the $48 \mathrm{~h}$ period after the event started, the event was excluded from the analysis. Altogether 21 new particle formation events were excluded. Examples of new particle formation events and the wind speed and direction during the events are shown in figures introduced in Sect. 3.

The lower limit of the instrument, $10 \mathrm{~nm}$ of the particle diameter, created a challenge of interpreting both the event starting time and the event duration. In addition, it was not certain whether new particle formation actually initiated onsite or whether we detected solely an appearance of a growing mode originating from particle formation that had occurred away from our station.

\subsubsection{Growth rate calculations}

Determining growth rates was not straightforward due to the unique nature of Antarctic events and we used several methods to determine growth rate depending on the type of event. For most of the normal events the method developed by Hirsikko et al. (2005) was used for determining growth rates. This method determines the particle growth by following the size class maximum. First, the times of the concentration maxima in each size class are defined. Then a line is fitted to the size class maximum times as function of size class diameter, and the slope of this line gives the growth rate. The method is limited for events in which the growth can be followed to larger sizes.

In case the of the normal events for which the method by Hirsikko et al. (2005) did not work, and in the case of slowly growing events, the growth rates were determined by mode-fitting method or by fitting a curve to the calculated geometric mean diameter. The mode-fitting method is based on the log-normal modes fitted to each number size distribution using the algorithm of Hussein et al. (2005). The method works by selecting the geometric mean diameter of the growing nucleation mode based on visual inspection of the daily contour plots of the particle size distributions. The growth rate is then obtained by a linear least-squares fit to these selected nucleation mode mean diameters as function of time. Further details of this method can be found in Dal Maso et al. (2005), Yli-Juuti et al. (2011) and Kulmala et al. (2012). The method for calculating the growth rate from the geometric mean diameter was similar to the method described above but used calculated geometric mean from measured data instead of mode data. In some cases two different methods of determining growth rate could be used for the same day and we had to choose the method that was qualitatively the best. The methods used for calculating the growth rate on each event day are given in Table 3. The errors of the growth rates were determined as the standard error of the linear fit.

\subsubsection{Formation rate, vapor concentration and source rate}

The formation rate of nucleation mode particles (in this case particles between 10 and $25 \mathrm{~nm}$ ) was calculated from the measured number concentration in this size range by taking into account particle losses due to coagulation and condensational growth out of the size range. The formation rate of $10 \mathrm{~nm}$ particles, $J_{10}$, can be written as (Dal Maso et al., 2005)

$J_{10}=\frac{\mathrm{d} N}{\mathrm{~d} t}+$ CoagS $\cdot N+\frac{\mathrm{GR}}{\Delta d_{\mathrm{p}}} \cdot N$,

where $N$ is the particle number concentration of $10-25 \mathrm{~nm}$ particles, CoagS is the coagulation sink due to pre-existing aerosol particles and GR is the particle growth rate over the size range of width $\Delta d_{\mathrm{p}}$. Coagulation sink for nucleation mode particles is calculated from the measured size distributions according to the method presented in Kulmala et al. (2012).

The condensational growth rate explained by certain vapor concentration $C_{\mathrm{v}}$ can be calculated using the formula (Nieminen et al., 2010)

$$
\begin{gathered}
\mathrm{GR}=\frac{2 \cdot K n \cdot \beta}{3 \cdot p_{\mathrm{v}}} \cdot\left(\frac{8 k T}{\pi}\right) \cdot\left(1+\frac{d_{\mathrm{v}}}{d_{\mathrm{p}}}\right)^{2} \\
\cdot\left(\frac{1}{m_{\mathrm{p}}}+\frac{1}{m_{\mathrm{v}}}\right)^{1 / 2} \cdot m_{\mathrm{v}} \cdot C_{\mathrm{v}},
\end{gathered}
$$

where $m_{\mathrm{v}}, d_{\mathrm{v}}$ and $\rho_{\mathrm{v}}$ are the vapor molecule mass, diameter and condensed phase density, $d_{\mathrm{p}}$ is the diameter of the grow- 
ing particle and $T$ the ambient temperature. $K n$ and $\beta$ are the Knudsen number and the Fuchs-Sutugin transition regime correction factor for mass flux, respectively. Equation (2) can be used to calculate the vapor concentration required to explain the observed particle growth rates. Assuming molecular properties of sulfuric acid for the condensing vapor, the concentration of $10^{7} \mathrm{~cm}^{-3}$ corresponds to the growth rate of $0.4 \mathrm{~nm} \mathrm{~h}^{-1}$ for nucleation mode (10-25 nm) particles.

The source rate $Q_{\mathrm{v}}$ for the condensing vapor can be calculated from the equation describing the evolution of vapor concentration:

$\frac{\mathrm{d} C_{\mathrm{v}}}{\mathrm{d} t}=Q_{\mathrm{v}}-\mathrm{CS} \cdot C_{\mathrm{v}}$.

In steady-state $\left(\mathrm{d} C_{\mathrm{v}} / \mathrm{d} t=0\right)$ the vapor source rate is

$Q_{\mathrm{v}}=\mathrm{CS} \cdot C_{\mathrm{v}}$.

Here the condensation sink CS onto aerosol particles is calculated from the measured particle size distributions according to Kulmala et al. (2012).

\subsubsection{Back-trajectory analysis}

Air parcel $96 \mathrm{~h}$ back trajectories were calculated using using the Hybrid Single-Particle Lagrangian Integrated Trajectory (HYSPLIT) Model (Draxler and Rolph, NOAA Air Res. Lab., Silver Spring, Maryland, http://www.arl.noaa.gov/ ready/hysplit4.html). A GDAS meteorological dataset was used in the calculations. Back trajectories were calculated for arriving at three different heights: $100 \mathrm{~m}, 500 \mathrm{~m}$ and $1000 \mathrm{~m}$ above the ground level.

\section{Results and discussion}

\subsection{General features and seasonal cycle}

Over 81000 size spectra were measured during the measurement period, from which over 76000 size spectra were used in the data analysis. We calculated the statistics separately for the summer (December-February), autumn (March-May), winter (June-August) and spring (September-November) seasons. In summer, sunlight was present all the time, whereas the winter months were completely dark. The average temperature in winter was $-63^{\circ} \mathrm{C}$ and in summer it was $-36^{\circ} \mathrm{C}$.

A clear seasonal cycle of the particle number concentrations was seen in the number size distribution data (Figs. 1 and 2). The particle number concentrations were at their lowest in July and August and at the highest in January. In Fig. 1 the short peaks in the particle number size distribution are mainly contamination from the station (in non-cleaned dataset). However, we observed also natural peaks in the particle number concentration, which indicated new particle formation. Altogether during the measurement period, we observed 60 natural new particle formation days, from which we could analyze particle formation and growth rates on 15 days as explained in detail in Sect. 3.2.

After cleaning the size distribution data, the total concentration of measured particles larger than $10 \mathrm{~nm}$ varied from 4 to $1300 \mathrm{~cm}^{-3}$ and the median total concentration was $94 \mathrm{~cm}^{-3}$. The median particle concentrations were 20 , 41 and $6 \mathrm{~cm}^{-3}$ in the nucleation, Aitken and accumulation modes, respectively. The geometric mean diameter of the measured particles varied from (5th and 95th percentile) 20 to $64 \mathrm{~nm}$ and the volume concentration varied from 0.004 to $0.140 \mu \mathrm{m}^{3} \mathrm{~cm}^{-3}$ (median value $0.033 \mu \mathrm{m}^{3} \mathrm{~cm}^{-3}$ ). The particle number concentrations observed at Dome $\mathrm{C}$ are lower than those in coastal Antarctica. For instance at Neumayer, the median number concentration of $25 \mathrm{yr}$ of CPC data was $258 \mathrm{~cm}^{-3}$ (Weller et al., 2011), which is $64 \%$ higher than our measured median total concentration. Other coastal measurements in the summer have shown concentrations in the range of $300-1000 \mathrm{~cm}^{-3}$ (Ito, 1993; Gras, 1993). At the South Pole, reported aerosol number concentrations were about $100-300 \mathrm{~cm}^{-3}$ in summer and below $20 \mathrm{~cm}^{-3}$ in winter (Shaw, 1988; Park et al., 2004). These values are close to the mean and average values measured at Dome C (Table 1).

The seasonal cycle in the particle number concentration was similar to those observed at other Antarctic sites: high concentrations in summer and low in winter. The median number concentration was $260 \mathrm{~cm}^{-3}$ and $15 \mathrm{~cm}^{-3}$ in summer and in winter, respectively (Table 1). At Neumayer the annual maximum number concentration of $1000 \mathrm{~cm}^{-3}$ was reported in March and the minimum number concentration of $<100 \mathrm{~cm}^{-3}$ was reported in June/July.

Weller et al. (2011) also detected a diurnal cycle in particle number concentrations at Neumayer. For particles larger than $7 \mathrm{~nm}$, this cycle was present for the months September through April but absent from May through August. The observations by Weller et al. (2011) do not differ much from our observations: at Dome $\mathrm{C}$ the diurnal cycle of particles larger than $10 \mathrm{~nm}$ was strongest in spring (September-November), not quite as strong in summer (December-February), and almost absent in both autumn and winter (Fig. 3). Weller et al. (2011) noted that the observed diurnal cycle is consistent with a photo-chemically induced process. The vicinity of the sea with higher aerosol and precursor gas concentrations is probably also affecting the diurnal cycles at Neumayer, whereas at Dome $\mathrm{C}$ diurnal cycles are most probably only of photochemical origin.

The same seasonal cycle as for the particle number concentration was also observed for the particle volume concentration (Fig. 2). The mean volume concentration was the highest in summer, $\sim 0.1 \mu \mathrm{m}^{3} \mathrm{~cm}^{-3}$ and the lowest in winter, $\sim 0.02 \mu \mathrm{m}^{3} \mathrm{~cm}^{-3}$ (Table 1). These numbers can be compared with the mass concentrations obtained from filter and impactor samples taken from Dome C, even though not simultaneously with our measurements. Udisti et al. (2012) analyzed filter and impactor samples from December 2004 to December 2007, which is not the same period as in our 
Table 1. Descriptive statistics of the total particle number concentration, geometric mean diameter and its geometric standard deviation, the particle volume concentration, modal mean diameters and their geometric standard devation, and growth rates during the four seasons.

\begin{tabular}{|c|c|c|c|c|c|c|}
\hline & \multicolumn{6}{|c|}{ Winter } \\
\hline & \multicolumn{6}{|c|}{ Percentile } \\
\hline & $\mathrm{N}$ & Mean & Std & $95 \%$ & $50 \%$ & $5 \%$ \\
\hline Total concentration & 18313 & 20.2 & 37.4 & 40.5 & 15.4 & 4.27 \\
\hline Geometric mean diameter $[\mathrm{nm}]$ & 19005 & 39.4 & 19.3 & 71.1 & 34.2 & 19.6 \\
\hline Geometric std of diameter & 19005 & 2.27 & 0.30 & 2.71 & 2.25 & 1.92 \\
\hline Volume concentration $\left[\mu \mathrm{m}^{3} \mathrm{~cm}^{-3}\right]$ & 19005 & 0.021 & 0.091 & 0.046 & 0.009 & 0.002 \\
\hline Diameter of mode $1[\mathrm{~nm}]$ & 16595 & 29.1 & 30.2 & 85.5 & 18.8 & 9.00 \\
\hline Diameter of mode $2[\mathrm{~nm}]$ & 3740 & 34.7 & 40.9 & 98.7 & 23.3 & 9.00 \\
\hline Diameter of mode $3[\mathrm{~nm}]$ & 231 & 64.6 & 61.6 & 213 & 46.3 & 9.00 \\
\hline Width of mode 1 & 16595 & 1.62 & 1.33 & 4.08 & 1.19 & $5.68 \mathrm{E}-07$ \\
\hline Width of mode 2 & 3740 & 2.00 & 1.26 & 4.30 & 1.69 & 1.02 \\
\hline Width of mode 3 & 231 & 1.77 & 0.97 & 4.22 & 1.38 & 1.07 \\
\hline GR $10-25 \mathrm{~nm}\left[\mathrm{~nm} \mathrm{~h}^{-1}\right]$ & 0 & - & - & - & - & - \\
\hline GR $\left.25-600 \mathrm{~nm}^{2} \mathrm{~nm} \mathrm{~h}^{-1}\right]$ & 1 & 0.500 & - & 0.500 & 0.500 & 0.500 \\
\hline \multirow[t]{4}{*}{ GR from growth limited events } & 0 & - & - & - & - & - \\
\hline & \multicolumn{6}{|c|}{ Summer } \\
\hline & \multicolumn{6}{|c|}{ Percentile } \\
\hline & & Mean & Std & $95 \%$ & $50 \%$ & $5 \%$ \\
\hline Total concentration & 20526 & 305 & 179 & 623 & 260 & 150 \\
\hline Geometric mean diameter [nm] & 22531 & 41.6 & 11.2 & 62.4 & 41.1 & 24.7 \\
\hline Geometric std of diameter & 22531 & 1.97 & 0.16 & 2.21 & 1.99 & 1.70 \\
\hline Volume concentration $\left[\mu \mathrm{m}^{3} \mathrm{~cm}^{-3}\right]$ & 22531 & 0.103 & 0.148 & 0.184 & 0.086 & 0.051 \\
\hline Diameter of mode $1[\mathrm{~nm}]$ & 21643 & 40.2 & 19.6 & 74.9 & 38.5 & 9.00 \\
\hline Diameter of mode $2[\mathrm{~nm}]$ & 11603 & 61.0 & 38.1 & 124 & 58.7 & 9.00 \\
\hline Diameter of mode $3[\mathrm{~nm}]$ & 6507 & 57.9 & 46.2 & 142 & 41.7 & 9.00 \\
\hline Width of mode 1 & 21643 & 1.92 & 0.590 & 2.67 & 1.85 & 1.35 \\
\hline Width of mode 2 & 11603 & 1.63 & 0.460 & 2.43 & 1.52 & 1.25 \\
\hline Width of mode 3 & 6507 & 1.58 & 0.480 & 2.35 & 1.47 & 1.19 \\
\hline 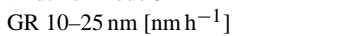 & 9 & 3.37 & 2.34 & 9.01 & 2.79 & 0.792 \\
\hline GR $25-600 \mathrm{~nm}\left[\mathrm{~nm} \mathrm{~h}^{-1}\right]$ & 7 & 0.640 & 0.410 & 1.13 & 0.780 & 0.210 \\
\hline \multirow[t]{4}{*}{ GR from growth limited events } & 0 & - & - & - & - & - \\
\hline & \multicolumn{6}{|c|}{ Autumn } \\
\hline & \multicolumn{6}{|c|}{ Percentile } \\
\hline & & Mean & Std & $95 \%$ & $50 \%$ & $5 \%$ \\
\hline Total concentration & 16957 & 131 & 145 & 421 & 87.1 & 24.0 \\
\hline Geometric mean diameter $[\mathrm{nm}]$ & 18467 & 35.4 & 11.3 & 55.5 & 33.7 & 20.5 \\
\hline Geometric std of diameter & 18467 & 2.03 & 0.140 & 2.26 & 2.03 & 1.80 \\
\hline Volume concentration $\left[\mu \mathrm{m}^{3} \mathrm{~cm}^{-3}\right]$ & 18467 & 0.043 & 0.239 & 0.080 & 0.024 & 0.007 \\
\hline Diameter of mode $1[\mathrm{~nm}]$ & 17843 & 32.4 & 21.3 & 76.5 & 29.7 & 9.00 \\
\hline Diameter of mode $2[\mathrm{~nm}]$ & 7791 & 48.5 & 31.9 & 104 & 40.3 & 9.00 \\
\hline Diameter of mode $3[\mathrm{~nm}]$ & 2772 & 46.3 & 37.4 & 110 & 35.0 & 9.00 \\
\hline Width of mode 1 & 17843 & 2.15 & 0.840 & 3.57 & 2.00 & 1.36 \\
\hline Width of mode 2 & 7791 & 1.79 & 0.580 & 2.96 & 1.60 & 1.25 \\
\hline Width of mode 3 & 2772 & 1.65 & 0.420 & 2.50 & 1.54 & 1.20 \\
\hline 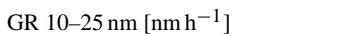 & 1 & 10.1 & - & 10.1 & 10.1 & 10.1 \\
\hline GR $25-600 \mathrm{~nm}\left[\mathrm{~nm} \mathrm{~h}^{-1}\right]$ & 1 & 0.230 & - & 0.230 & 0.230 & 0.230 \\
\hline \multirow[t]{4}{*}{ GR from growth limited events } & 2 & 1.26 & 0.050 & 1.29 & 1.26 & 1.22 \\
\hline & \multicolumn{6}{|c|}{ Spring } \\
\hline & \multicolumn{6}{|c|}{ Percentile } \\
\hline & & Mean & Std & $95 \%$ & $50 \%$ & $5 \%$ \\
\hline Total concentration & 20351 & 138 & 176 & 457 & 85.8 & 17.9 \\
\hline Geometric mean diameter $[\mathrm{nm}]$ & 19005 & 34.5 & 16.4 & 66.2 & 29.8 & 15.8 \\
\hline Geometric std of diameter & 21667 & 1.99 & 0.250 & 2.46 & 1.95 & 1.66 \\
\hline Volume concentration $\left[\mu \mathrm{m}^{3} \mathrm{~cm}^{-3}\right]$ & 21670 & 0.057 & 0.220 & 0.098 & 0.030 & 0.007 \\
\hline Diameter of mode $1[\mathrm{~nm}]$ & 19713 & 32.4 & 27.4 & 91.2 & 24.0 & 9.00 \\
\hline Diameter of mode $2[\mathrm{~nm}]$ & 11084 & 38.3 & 28.1 & 93.3 & 30.0 & 9.00 \\
\hline Diameter of mode $3[\mathrm{~nm}]$ & 3649 & 40.4 & 36.4 & 113 & 34.5 & 9.00 \\
\hline Width of mode 1 & 19713 & 1.86 & 0.830 & 3.48 & 1.62 & 1.05 \\
\hline Width of mode 2 & 11084 & 1.75 & 0.690 & 2.94 & 1.56 & 1.16 \\
\hline Width of mode 3 & 3649 & 1.75 & 0.650 & 2.93 & 1.56 & 1.20 \\
\hline 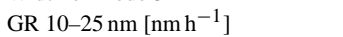 & 2 & 13.3 & 1.13 & 14.1 & 13.3 & 12.5 \\
\hline GR $25-600 \mathrm{~nm}\left[\mathrm{~nm} \mathrm{~h}^{-1}\right]$ & 2 & 3.30 & 3.17 & 5.32 & 3.30 & 1.29 \\
\hline GR from growth limited events & 1 & 0.490 & - & 0.490 & 0.490 & 0.490 \\
\hline
\end{tabular}


Table 2. Descriptive statistics for data that came from the polluted sector.

\begin{tabular}{lrrrrrr}
\hline & \multicolumn{6}{c}{ Percentile } \\
\cline { 2 - 6 } & $N$ & Mean & Std & $95 \%$ & $50 \%$ & $5 \%$ \\
\hline Total concentration $\left[\mathrm{cm}^{-3}\right]$ & 5412 & 910 & 4250 & 2620 & 245 & 18.2 \\
Geometric mean diameter $[\mathrm{nm}]$ & 5411 & 37.1 & 16.2 & 62.2 & 34.7 & 18.4 \\
Geometric std of diameter & 5411 & 2.05 & 0.260 & 2.48 & 2.04 & 1.68 \\
Volume concentration $\left[\mathrm{\mu m}^{3} \mathrm{~cm}^{-3}\right]$ & 5413 & 0.210 & 0.634 & 0.941 & 0.070 & 0.008 \\
\hline
\end{tabular}
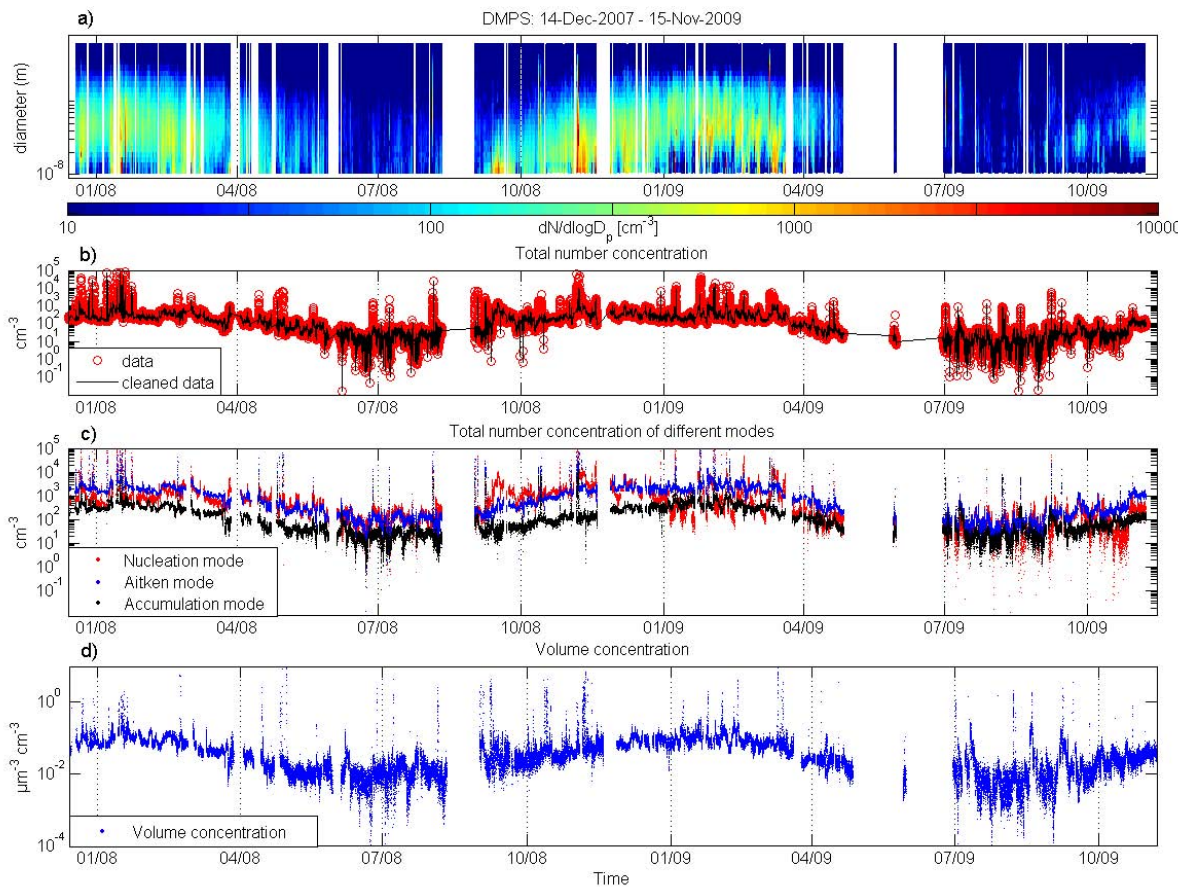

Fig. 1. Time series of (a) the particle number size distribution, (b) total particle number concentration, (c) total particle number concentrations in the nucleation, Aitken mode and accumulation mode size ranges, and (d) the total particle volume concentration.

work, yet the general level can be compared. They did not weigh the samples but analyzed them for the concentrations of major ionic constituents. In addition, they did not present the total concentrations but the concentrations of sea salt and its contribution to the sum of analyzed ions for particles with $D_{\mathrm{p}}<10 \mu \mathrm{m}$. The $3 \mathrm{yr}$ average concentration of sea salt was $10.7 \mathrm{ng} \mathrm{m}^{-3}$ in summer and $58.8 \mathrm{ng} \mathrm{m}^{-3}$ in winter. The respective average contributions were $11.2 \%$ and $84.3 \%$, so it can be calculated that in the data of Udisti et al. (2012), the average mass concentrations were $\sim 96 \mathrm{ng} \mathrm{m}^{-3}$ in summer and $\sim 70 \mathrm{ng} \mathrm{m}^{-3}$ in winter. The average volume concentrations calculated from our DMPS data were $0.103 \mu^{3} \mathrm{~cm}^{-3}$ and $0.021 \mu \mathrm{m}^{3} \mathrm{~cm}^{-3}$ in summer and winter, respectively (Table 1). If it is assumed that the particle density is that of water, $1 \mathrm{~g} \mathrm{~cm}^{-3}$, the mass concentrations were $103 \mathrm{ng} \mathrm{m}^{-3}$ and $21 \mathrm{ng} \mathrm{m}^{-3}$ in summer and winter, respectively. With the density of ammonium sulfate, $1.8 \mathrm{~g} \mathrm{~cm}^{-3}$, the concentrations would be $185 \mathrm{ng} \mathrm{m}^{-3}$ in summer and $38 \mathrm{ng} \mathrm{m}^{-3}$ in winter. It has to be noted here that the samplers of Udisti et al. (2012) were at ambient relative humidity, whereas the DMPS sample air got warmer and thus drier when taken into the laboratory air. However, the difference in the relative humidity on the roof and in the DMPS does not change the conclusion. The higher relative humidity in the impactor on the roof just moves the size distribution towards somewhat larger sizes but does significantly not change the total PM10 mass concentration that was compared here with the DMPS-derived mass concentration. The above calculations show that aerosol mass concentrations derived from two very different types of measurements were of similar magnitude. However, a detailed comparison needs to be performed for a period when both number size distribution measurements and chemical sampling are being conducted simultaneously.

We compared particle concentrations in nucleation, Aitken and accumulation size ranges. The particle number concentration in the nucleation and Aitken mode ranges were typ- 
Table 3. Particle growth rates (GR) and the standard error of the growth rate in the $10-25 \mathrm{~nm}$ size range, the derived formation rate $\left(J_{10}\right)$ and vapor concentrations $(\mathrm{CV})$ required to explain the observed growth (the vapor is assumed to have properties of sulfuric acid) and condensation sink (CS) values during the particle formation. The methods used to determine growth rate were to fit a curve to the geometric mean diameter (A), to use the method presented by Hirsikko et al. (2005) (B), and to fit a curve to calculated mode data (C).

\begin{tabular}{llllll}
\hline Date & Method & $\begin{array}{l}\mathrm{GR} \\
\left(\mathrm{nm} \mathrm{h}^{-1}\right)\end{array}$ & $\begin{array}{l}J_{10} \\
\left(\mathrm{~cm}^{-3} \mathrm{~s}^{-1}\right)\end{array}$ & $\begin{array}{l}C_{\mathrm{V}} \\
\left(10^{7} \mathrm{molec} \mathrm{cm}^{-3}\right)\end{array}$ & $\begin{array}{l}\mathrm{CS} \\
\left(10^{-4} \mathrm{~s}^{-1}\right)\end{array}$ \\
\hline 9.1 .2008 & $\mathrm{~B}$ & $4.6 \pm 1.3$ & 0.023 & 10.5 & 2.1 \\
10.1 .2008 & $\mathrm{~B}$ & $2.4 \pm 1.0$ & 0.020 & 5.5 & 3.8 \\
26.2 .2008 & $\mathrm{~B}$ & $3.4 \pm 1.9$ & 0.022 & 7.9 & 1.7 \\
3.3 .2008 & $\mathrm{~B}$ & $10.1 \pm 1.5$ & 0.084 & 23.3 & 1.9 \\
9.5 .2008 & $\mathrm{~A}$ & $1.3 \pm 0.4$ & 0.0012 & 3.0 & 0.3 \\
3.10 .2008 & $\mathrm{~A}$ & $0.5 \pm 0.02$ & 0.0022 & 1.1 & 0.3 \\
29.11 .2008 & $\mathrm{~B}$ & $12.5 \pm 1.6$ & 0.083 & 28.8 & 1.7 \\
29.11 .2008 & $\mathrm{~B}$ & $14.1 \pm 2.1$ & 0.11 & 32.5 & 2.2 \\
11.12 .2008 & $\mathrm{C}$ & $4.6 \pm 0.6$ & 0.030 & 10.6 & 2.3 \\
20.12 .2008 & $\mathrm{C}$ & $0.8 \pm 0.07$ & 0.053 & 1.8 & 2.5 \\
23.12 .2008 & $\mathrm{C}$ & $3.1 \pm 0.9$ & 0.016 & 7.1 & 1.8 \\
30.1 .2009 & $\mathrm{~B}$ & $1.6 \pm 0.2$ & 0.041 & 3.6 & 2.5 \\
22.2 .2009 & $\mathrm{~B}$ & $1.7 \pm 0.3$ & 0.0043 & 3.9 & 1.0 \\
24.2 .2009 & $\mathrm{~B}$ & $2.5 \pm 0.2$ & 0.017 & 5.7 & 1.7 \\
11.3 .2009 & $\mathrm{~B}$ & $1.2 \pm 0.3$ & 0.071 & 2.8 & 1.8 \\
Average & & 4.3 & 0.038 & 9.9 & 1.8 \\
Median & & 2.5 & 0.023 & 5.7 & 0.9 \\
Std & & 4.4 & 0.034 & 10.0 & \\
\hline
\end{tabular}
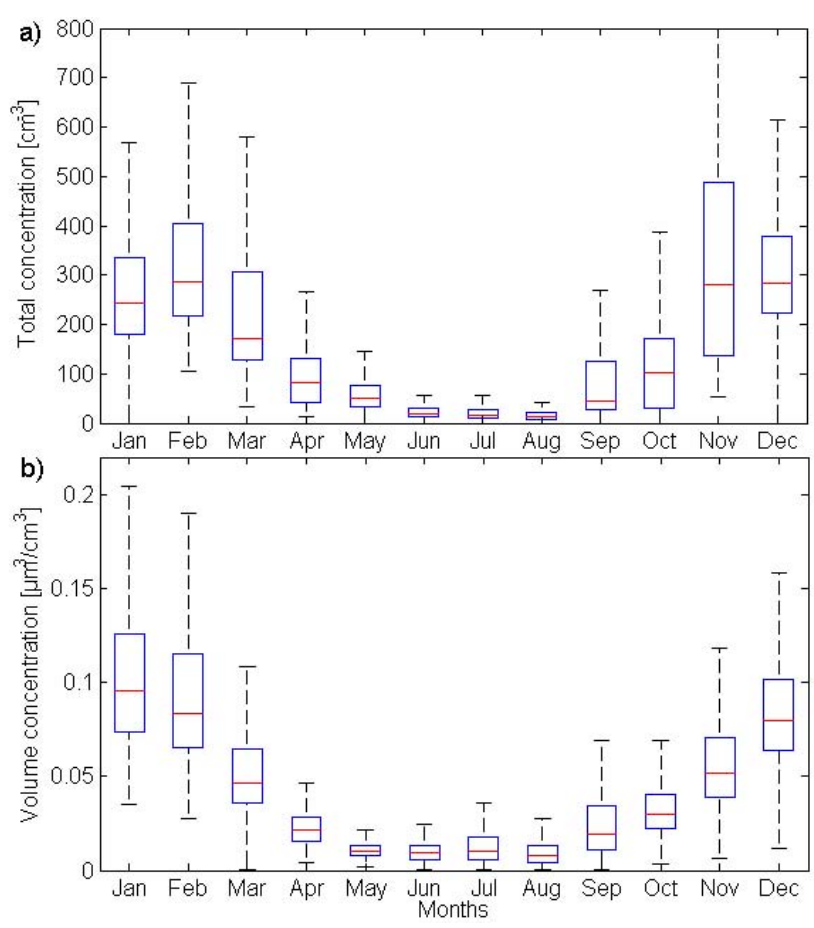

Fig. 2. The annual cycle of (a) total number concentration and (b) volume concentration. The red bars present the median value of volume concentration, the blue box the 25th and 75th percentiles and the black bars the 5 th and 95 th percentiles.
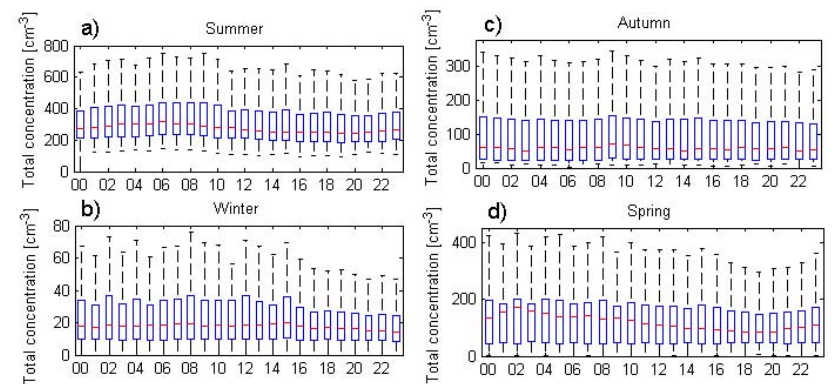

Fig. 3. The diurnal cycle of total number concentration in (a) summer, (b) winter, (c) autumn and (d) spring. Red bars present the median value of total concentration, blue box the 25 th and 75 th percentile and black bars the 5th and 95th percentile.

ically relatively similar to each other, whereas those in accumulation mode were approximately one order of magnitude lower (Fig. 1). The particle number concentrations were highest in the nucleation mode during our measurements, except periodically in the summer months of 2008 and 2009 when the particle number concentration was the highest in the Aitken mode. In summer time, we could see the growth of newly formed particles into the Aitken mode. The particle number concentrations were usually lowest in the accumulation mode, which indicates that the majority of the growing particles did not reach sizes above $100 \mathrm{~nm}$. The particle number concentrations in all the size classes followed the same 

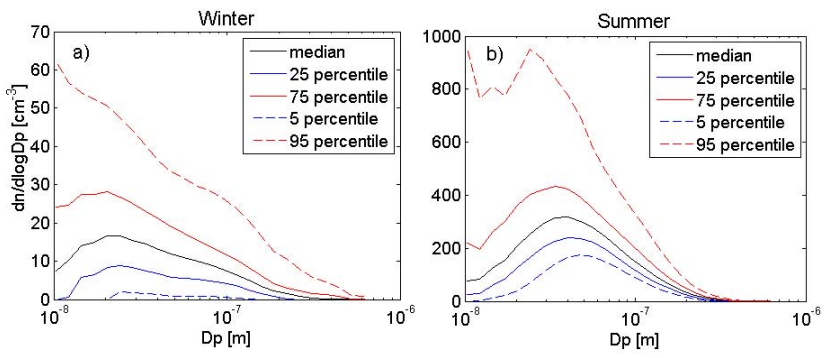

Fig. 4. The seasonal fractals of particle number size distributions (a) in winter (June-August) and (b) in summer (December-February). The black line represents the median concentration, the solid blue line the 25th percentile, the dashed blue line the 5th percentile, the solid red line the 75th percentile and the dashed red line the 95th percentile.

seasonal cycle with a summer maximum and winter minimum.

To further visualise the differences in the size distributions between the summer and winter, simple descriptive statistics were calculated, i.e., cumulative concentrations in each size channel of the data (Fig. 4). Figure 4 shows clearly that the modes of the size distributions were smaller in winter than in summer. In winter the mode of the median size distribution was at about $20 \mathrm{~nm}$ and in summer at about $40 \mathrm{~nm}$. We also found that in summer particle number concentrations were higher in every size class.

\subsection{Modal structure of measured particle size spectra}

We studied the modal structure of the particle size distributions by using the automatic mode-fitting algorithm discussed above. We compared the modes calculated with the algorithm to measured particle size distribution data (Fig. 5). The cumulative sum of the fitted modes matched the measured size distribution well, both in the case where there are three modes present as well as when only one mode was observed.

We wanted to study the occurrence of the fitted modes and at which sizes the modes are fitted (median diameter of modes). If one mode was present, the median diameter of the fitted mode was $19 \mathrm{~nm}$ in the winter and $39 \mathrm{~nm}$ in the summer. When two or more modes were present, particles were found in smaller sizes. This indicates that the strongest new particle formation events occurred in summer and, as explained above, the growth did not reach sizes of the accumulation mode. Also in winter when the second and the third mode had the same median values, particles were found in smaller sizes when three modes were observed than when only one or two modes were observed.

Figure 6 shows the relative frequency of the modes calculated by the automatic algorithm and how they fit to the nucleation mode, Aitken mode and the accumulation mode size range. We calculated the relative frequency by summing
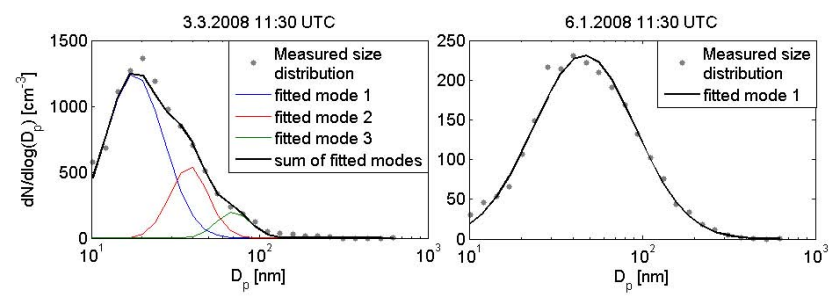

Fig. 5. Measured particle number size distribution (grey dots) and calculated modes with mode fitting algorithm (Hussein et al., 2005). In (a) three modes were present on 3 March 2008 and in (b) one mode was present on 6 January 2008.

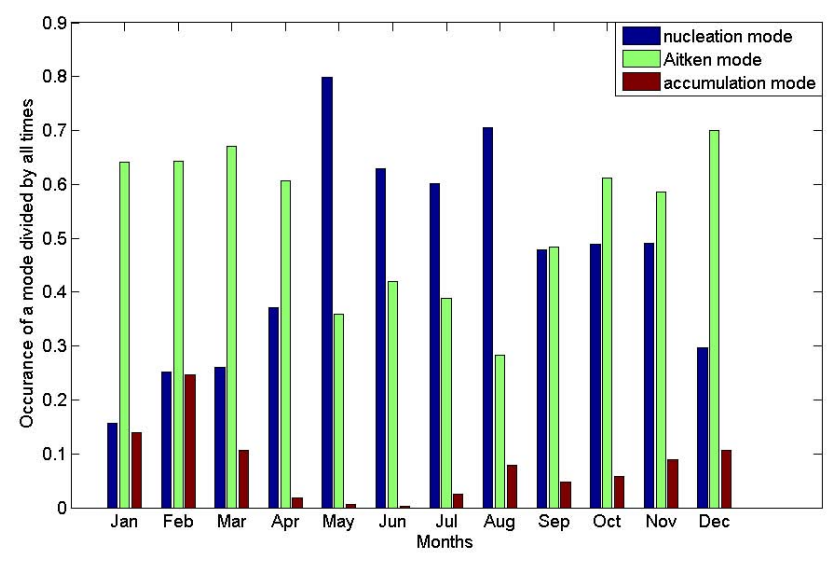

Fig. 6. Fraction of times, when one or more modes were found in the nucleation, Aitken or accumulation mode size ranges. If two or more modes were found in the same size range, the fractions of modes were added together.

up the occurrence of the modes in the nucleation, Aitken and accumulation size range in each month and dividing it with the number of modes in each month. When the particle number concentration was low (in winter), most of the time only one mode was present. When the new particle formation took place or particle number concentrations were high, usually three modes were found. The automatic algorithm fitted most of the modes in nucleation mode or Aitken size range. We found that most of the modes were in the nucleation size range from May to August when the total concentrations were the lowest, whereas other months most of the modes were in the Aitken size range. The occurrence of fitted modes in the accumulation size range was the highest during winter months when nucleation was most frequently observed and the particles were also able to grow to bigger sizes. This all indicates that the particles in the high Antarctic east-plateau air are small and that they are growing either slowly or not at all.

\subsection{New particle formation and growth}

We classified the days with respect to new particle formation into class 1 event days, class 2 event days, apple events (Vana 


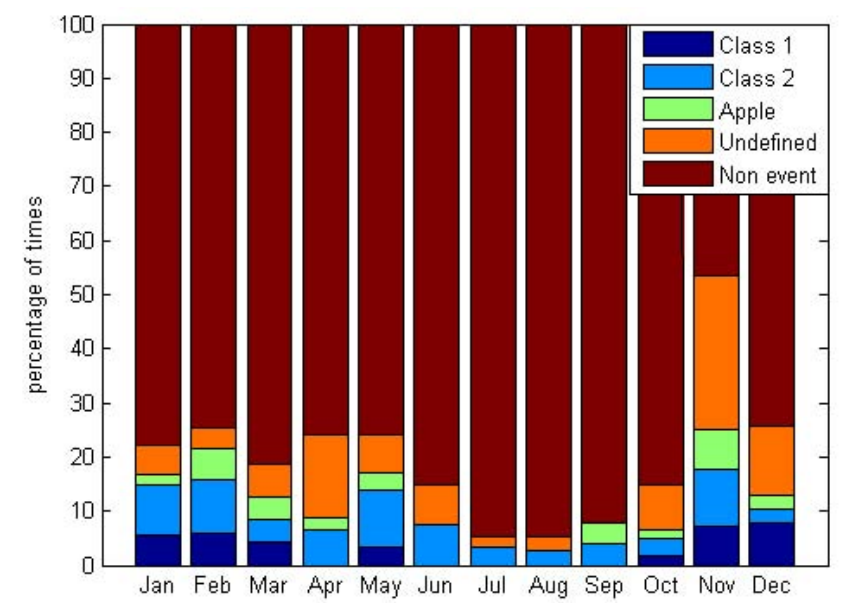

Fig. 7. Event classification from the whole period given as the monthly percentage of the class 1 event days (dark blue), class 2 event days (light blue), apple event days (green), undefined days (orange) and non-event days (dark red).

et al., 2008), undefined days and non-event days (Fig. 7). Before the analysis the contamination events were excluded from the event days (Fig. 8). We observed event days mainly in the Antarctic summer, and the event frequency was peaking in November and February. In 22 February percent of the days were event days. The month with the lowest occurrence of events was July when we observed events in 4 percent of the days. Most of the events belonged to the class 2, which means that the particle growth rate could not be determined. We observed class 1 events during all the summer months and also in March, May, October and November. The highest fraction of class 1 events was observed in November and December, roughly $7 \%$ of all the days were event days. The fraction of undefined days varied from 0 to 29 percent, the highest percentage being in November. The fraction of nonevent days varied from 46 to 95 percent.

To further analyze the different events, we divided the class 1 events into "normal" events and "slowly growing" events. By normal event we mean similar kinds of events that have been observed practically all over the world in different environments (Kulmala et al., 2004), whereas slowly growing event are characterized by the continuous and slow particle growth of up to several days. Nine of the 13 normal events (for an example see Fig. 9) were observed during the Antarctic summer. The continuous growth of the nucleated particles during several hours suggests that the new particle formation occurs in an area that is from tens of kilometres up to hundreds of kilometres wide, depending on the wind conditions. Since the distance from Dome $\mathrm{C}$ to the nearest coastline is several hundred kilometres, this means that the newly formed particles were growing when the measured air masses were already over the plateau of Antarctica.

Apple events took place in most of the months, excluding winter months and we observed them during 0 to 7 percent of
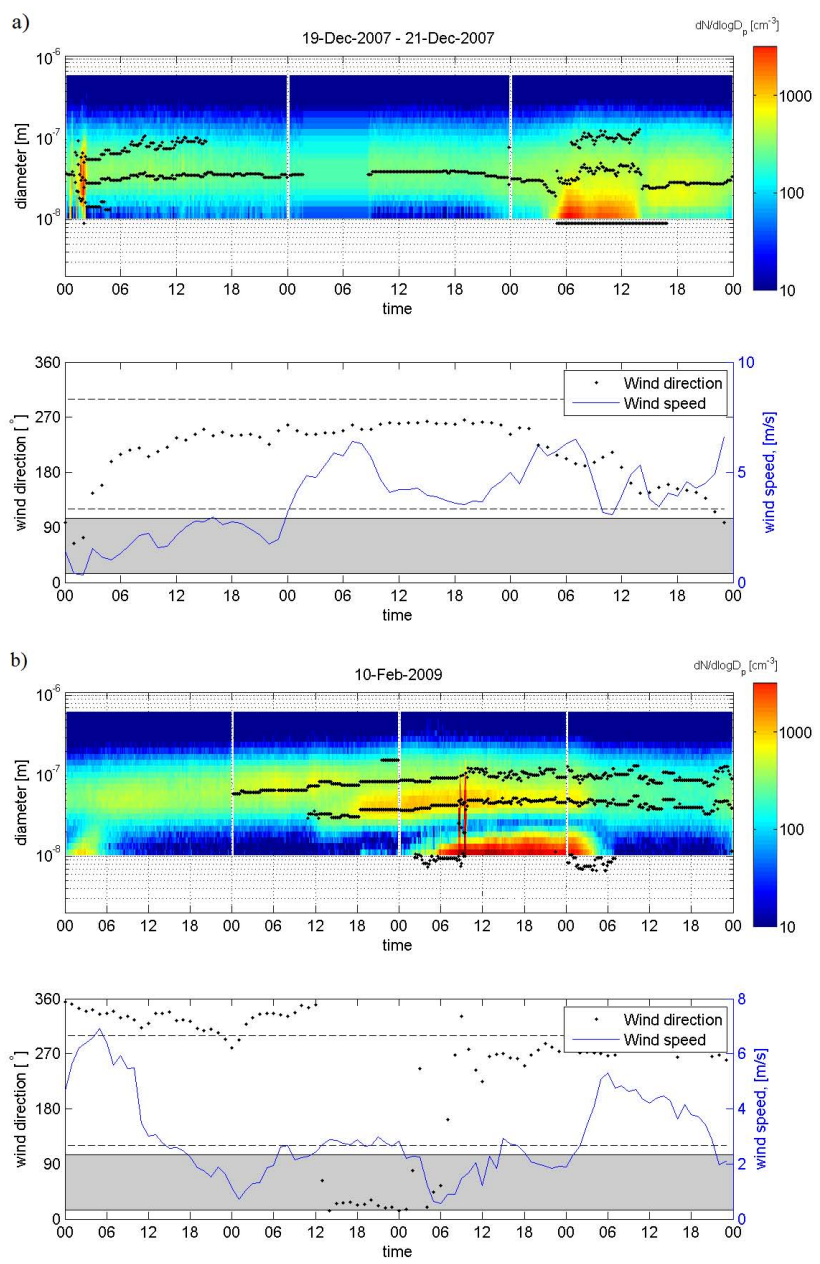

Fig. 8. Examples of quality check of the event analysis. In cases (a) and (b) the upper figure shows particle number size distributions and fitted mode (black dots) during two days before an event and the event day, and the lower figure represents the wind direction (dots) and wind speed (blue line) from the same period. The shaded area represents the contaminated wind direction sector. Dashed lines rule the area of wind direction where most of the clean events come. Event (a) was a real event and event (b) was excluded.

the days depending on the month. In apple events nucleation occurs in a more localized area than in the class 1 events, and these locally formed particles arrive at the measurement station after they have grown a certain time, which depends on the air mass properties. This event type has been previously shown to be typical for new particle formation in coastal regions, where this phenomenon is connected with coastal emissions following the low tide (Ehn et al., 2010). Apple events have also been observed at the near-coastal Antarctica site Aboa (Asmi et al., 2010; Kyrö et al., 2013). In our measurements, the classification of apple events was somewhat uncertain because we could not be sure from which sizes the new-particle formation started and how the event was shaped at sizes below $10 \mathrm{~nm}$. 


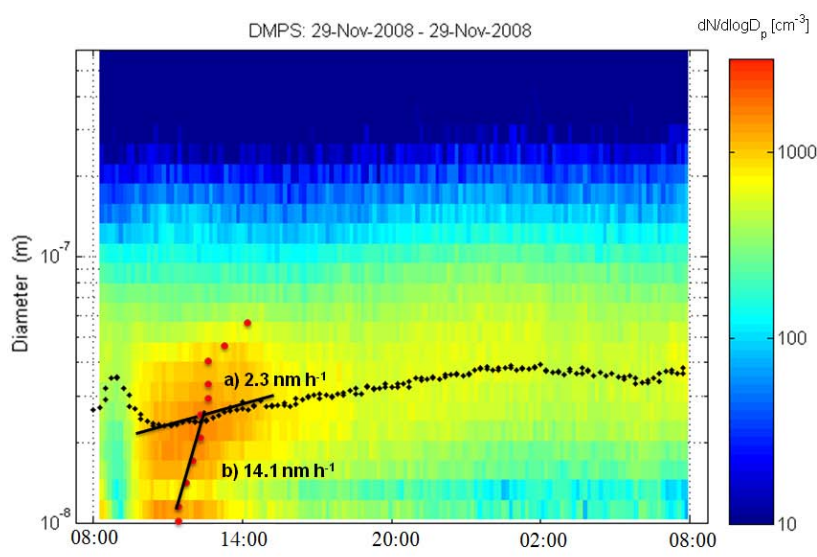

Fig. 9. New particle formation event on 29 November 2008. Black dots represent the calculated geometric mean diameter and red dots the maximum of mode. Black lines are the fitted slopes where growth rate was determined. Slope (a) is fitted to the geometric mean and slope (b) to the maximum of modes. The methods represented here work in the different parts of the growth. The growth rate (b) was used in to describe the early growth of the particles and the growth rate (a) the later growth. The time axis is in UTC $+8 \mathrm{~h}$.

At Dome $\mathrm{C}$ there were two kinds of events that have not been often observed at other locations. These were the slowly growing events mentioned above and wintertime events (Fig. 10). From the slowly growing events, particle growth rates could be calculated and the growth could be followed for up to three days. The winter events took place in the Antarctic winter when sunlight was not present and particle concentrations were extremely low. Some previous studies have also reported on night-time events taking place in the absence of solar radiation (e.g. Junninen et al., 2008; Suni et al., 2008), but the exact mechanisms and vapors involved are yet unclear (Ortega et al., 2012). Also the duration of the night-time events reported by Junninen et al. (2008) and Suni et al. (2008) were shorter than the winter events observed in our study. While it is possible that the particle formation in Antarctic dark winter has a connection to these night-time dark events, it seems still more likely that the mechanism in this specific environment is unique.

We studied the beginning times of the observed class 1 and class 2 events in local time. We used as a local time UTC + $8 \mathrm{~h}$. About $38 \%$ of the observed events started during morning hours (06:00-10:00), similarly to other observed events in boreal forests and other surroundings. In winter, two out of three events started at around 20:00, while all the other events started at 08:00. Events starting in the evening were observed also during other seasons. In summer, spring and autumn $25 \%, 38 \%$ and $36 \%$ of the events, respectively, started after 17:00. Four nocturnal events were observed: three in spring and one in autumn.

Growth rates and statistics were calculated for all the class 1 events (Table 3 ) and for each event type: for normal events

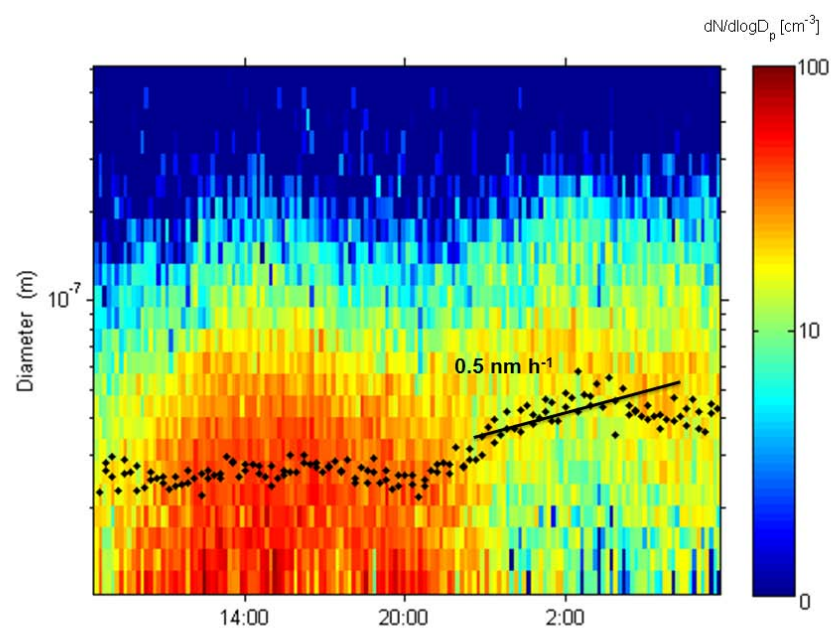

Fig. 10. New particle formation event during dark time in Antarctic winter on 11 June 2008. Black dots represent the calculated geometric mean diameter and black line the fitted slope where growth rate for $25-600 \mathrm{~nm}$ was determined. Notice the different color scale. The time axis is in UTC $+8 \mathrm{~h}$.

in the size ranges of $10-25 \mathrm{~nm}$ and $25-100 \mathrm{~nm}$ and for slowly growing events in the size range of $10-25 \mathrm{~nm}$ (Fig. 11). We were unable to determine the growth rate in the size range of $25-100 \mathrm{~nm}$ for either slowly growing events or winter events, since the growth could not be followed above $25 \mathrm{~nm}$ in those cases. The statistics were calculated season-wise.

The growth rate of all the class 1 events varied from 0.5 to $14 \mathrm{~nm} \mathrm{~h}^{-1}$ in the size range $10-25 \mathrm{~nm}$, and the median growth rate was $2.5 \mathrm{~nm} \mathrm{~h}^{-1}$ based on 15 events (Table 3). These values are comparable to those usually observed in continental rural and clean sites (e.g. Kulmala et al., 2004; Manninen et al., 2010; Asmi et al., 2011). Most of the class 1 events were normal events. We were able to determine the growth rate statistics of normal events only for summer when the growth rate varied from 0.8 to $4.6 \mathrm{~nm} \mathrm{~h}^{-1}$ with the median of $2.5 \mathrm{~nm} \mathrm{~h}^{-1}$. In spring we were able to derive only two growth rates and in autumn only one growth rate from the total of 25 events observed during those seasons, but all being of unusually high values in Antarctica. The median growth rate of normal events in the size range of 25 to $100 \mathrm{~nm}$ was $0.8 \mathrm{~nm} \mathrm{~h}^{-1}$. For the slowly growing events the median growth rate was $1.0 \mathrm{~nm} \mathrm{~h}^{-1}$, indicating low concentrations of condensable gases. The mean standard error of the derived growth rates was $21 \%$, which means that exact quantification of growth rates is difficult, but nevertheless we are able to prove that faster growth of the early nucleation mode is present.

The formation rates of $10 \mathrm{~nm}$ particles, $J_{10}$, of the class 1 events varied from 0.0043 to $0.11 \mathrm{~cm}^{-3} \mathrm{~s}^{-1}$ with the median of $0.023 \mathrm{~cm}^{-3} \mathrm{~s}^{-1}$ (Table 3). The median formation rate of $10 \mathrm{~nm}$ particles in Dome $\mathrm{C}$ is about an order of magnitude smaller than that measured at a coastal Antarctic station 

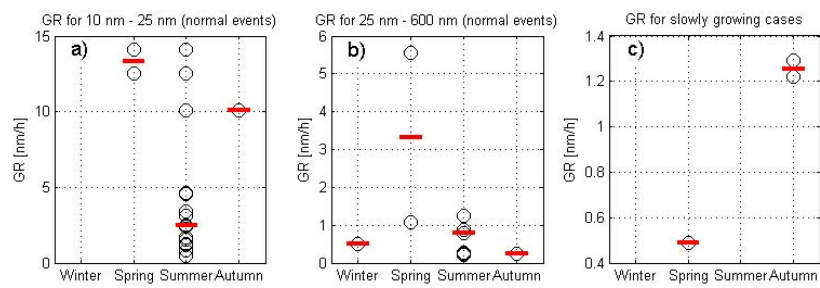

Fig. 11. Seasonal growth rate statistics for (a) the growth rates of normal events in the size range of $10-25 \mathrm{~nm}$, (b) the growth rates of normal events in the size range of $25-600 \mathrm{~nm}$ and (c) the growth rates determined from the slowly growing events. The seasons were winter (June, July, August), spring (September, October, November), summer (December, January, February) and autumn (March, April, May). Concerning the normal events in the size class of 10 to $25 \mathrm{~nm}$, the growth rate statistics for spring were determined from two cases, for summer from 10 cases and for autumn from one case. Concerning the normal events in the size class of $>25 \mathrm{~nm}$, the growth rate statistics for winter were determined from one case, for spring from two cases, for summer from seven cases and for autumn from one case. Concerning the slowly growing events, the growth rate for spring was determined from one case and for autumn from two cases.

Aboa or at a boreal forest site in Hyytiälä, Finland (Table 4). The value of the condensation sink varied from 0.00003 to $0.00038 \mathrm{~s}^{-1}$ with the median of $0.00018 \mathrm{~s}^{-1}$ in Dome C. These values are similar to those observed in Aboa, but about a magnitude lower than those observed in Hyytiälä (Table 4). Figure 12 shows the relation between the average values of $J_{10}$ and CS during the class 1 events. There seems to an overall tendency of more intense new particle formation at higher values of the condensation sink. Since the condensation sink is closely related to the aerosol surface area and submicron aerosol mass concentration, this connection might suggest that the air masses having more particulate matter have also more vapors participating in new particle formation.

It is unknown which vapors condenses onto newly formed aerosol particles and make them grow (e.g. Riipinen et al., 2011). Since sulfuric acid is very likely involved in new particle formation and early growth, we used Eq. (2) here to estimate how high sulfuric acid concentration would be needed for explaining the observed growth. The calculated vapor concentrations in the 15 class 1 events varied from 1.1 to $32 \times 10^{7} \mathrm{~cm}^{-3}$ with the median of $5.7 \times 10^{7} \mathrm{~cm}^{-3}$. Mauldin et al. $(2001,2004)$ measured sulfuric acid concentration at the South Pole in the Antarctic summer. The median concentration was $2.7 \times 10^{5} \mathrm{~cm}^{-3}$. If sulfuric acid concentrations at Dome $\mathrm{C}$ are similar to those in the South Pole, this compound can explain only a small fraction of the particle growth rate in there.

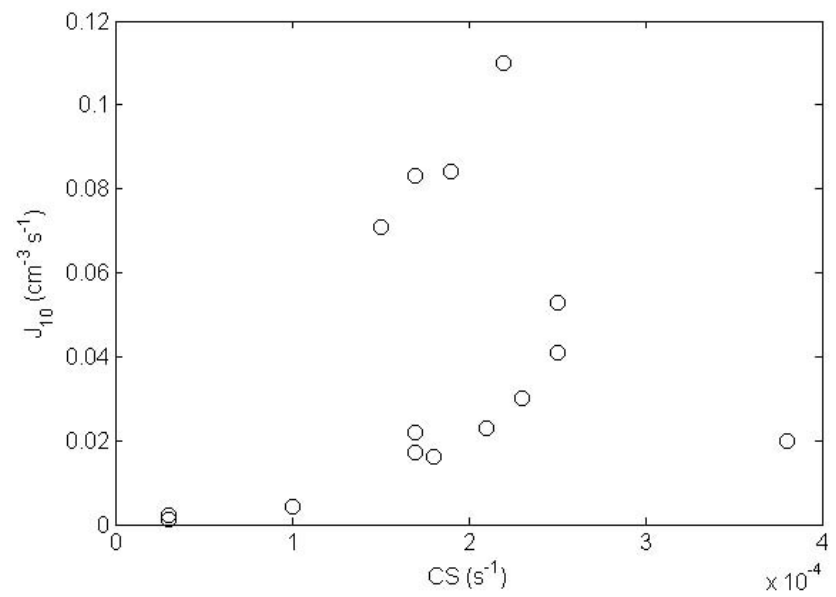

Fig. 12. The formation rate of $10 \mathrm{~nm}$ particles as a function of the condensation sink for the class 1 events.

\subsection{Origins and atmospheric pathways of particles reaching Dome $\mathrm{C}$ during nucleation events}

In order to study the origin and possible transport pathways of particles reaching the Dome $\mathrm{C}$ station during class 1 and class 2 nucleation events, we calculated 4-day back trajectories that arrived at the station at the starting times of all the class 1 and class 2 events. The trajectories were calculated for three heights: $100 \mathrm{~m}, 500 \mathrm{~m}$ and $1000 \mathrm{~m}$ above the ground level. All of the calculated back trajectories for the class 1 event days came from inland, as well as the majority of all the calculated class 2 back trajectories. Most of the inland trajectories travelled close to the South Pole. The trajectories travelled a median distance of $1400 \mathrm{~km}$ during last four days before arriving at the measurement station.

It has been shown that a strong inversion is present at Dome C station throughout the year, except in December and January (Busetto et al., 2013; Genthon et al., 2010; Hudson and Brandt, 2005). In order to determine whether the measured air masses came from the inversion layer, we studied the vertical profiles of the back trajectories calculated to arrive at height $100 \mathrm{~m}$ (Fig. 13). The majority of the class 1 event back trajectories (Fig. 13a) and class 2 event back trajectories from the sea (Fig. 13c) originated at altitudes higher than $400 \mathrm{~m}$ that is above the inversion layer (Busetto et al., 2013). The shapes of the vertical profiles of the back trajectories are explainable with the circulation induced by the Antarctic drainage flow (James, 1989), resulting in that the origin of the particles measured during the class 1 events and some of the class 2 events were from the upper troposphere. In such circulation, air from upper troposphere is transported down to boundary layer in the central parts of Antarctica and then transported towards the coast by katabatic winds.

In contrast, the majority of the class 2 events that originated from land originated at altitudes below $400 \mathrm{~m}$ (Fig. 13b), which indicates that the measured particles came 
Table 4. The comparison of growth rate (GR), formation rate $\left(J_{10}\right)$ and condensation sink (CS) between Dome C, Aboa and Hyytiälä. The Aboa values represent the medians and ranges during the new particle formation events in January, 2010 (Kyrö et al., 2013). The GR values from Hyytiälä are the median and 10th to 90th percentile range of 809 new particle formation events, the value of CS value is the geometric mean of CS during these events, and $J_{10}$ represents the median $10 \mathrm{~nm}$ particle formation rate (Dal Maso et al., 2007).

\begin{tabular}{llll}
\hline & Dome C & Aboa & Hyytiälä \\
\hline $\mathrm{GR}\left(\mathrm{nm} \mathrm{h}^{-1}\right)$ & 2.5 & $5.5(1.8-8.8)$ & $2.5(1.1-5.3)$ \\
$J_{10}\left(\mathrm{~cm}^{-3} \mathrm{~s}^{-1}\right)$ & 0.023 & $0.2(0.003-0.3)$ & 0.4 \\
$\mathrm{CS}\left(\mathrm{s}^{-1}\right)$ & 0.00018 & 0.00040 & 0.0017 \\
\hline
\end{tabular}

from the inversion layer. Since the air mass travelled a distance of $\sim 1000 \mathrm{~km}$, we can rule out that the events were caused by contamination from the station that would have stayed in the inversion layer. However it is possible that the some of the class 2 events occurred locally somewhere further, and that we observed at Dome $\mathrm{C}$ those parts of the events that were preserved in the inversion layer. A further study of the origin of the particles observed at nucleation event days is not possible in the framework of this study. Based on older studies, we can speculate that the majority of the compounds reaching Dome $\mathrm{C}$ originate from the sea. Cosme et al. (2005) reported that oceans contribute more than $90 \%$ of the sulphate measured at Vostok station, close to Dome C. They also reported that volcanoes and anthropogenic sources contribute relatively more to the sulphate in inland than at coast. This might also be the case at Dome $\mathrm{C}$ due to the Antarctic circulation, supported by Fig. 13a and c.

\section{Conclusions}

We observed a clear seasonal cycle in the particle number concentrations, similar to that reported for other Antarctic stations. However, this study was the first one that presents the seasonal cycle of the frequency of the main three modes of the aerosol submicron number size distributions: the nucleation, Aitken and accumulation mode. An automatic algorithm was used to calculate modes from the particle size distribution data. The automatically fitted modes were located mainly in the nucleation and Aitken size ranges. Overall, the great majority of the particles were found in sizes below $100 \mathrm{~nm}$ of particle diameter, which is probably due to small amount of condensable vapours.

New particle formation events were observed in every month, and this phenomenon was most frequent during the summer months. A new finding was the winter events, which was not expected as there is no sunlight during winter. The apparent growth of particles during the winter events was limited, so we were not able to determine particle growth rates at sizes below $25 \mathrm{~nm}$. Another interesting finding was
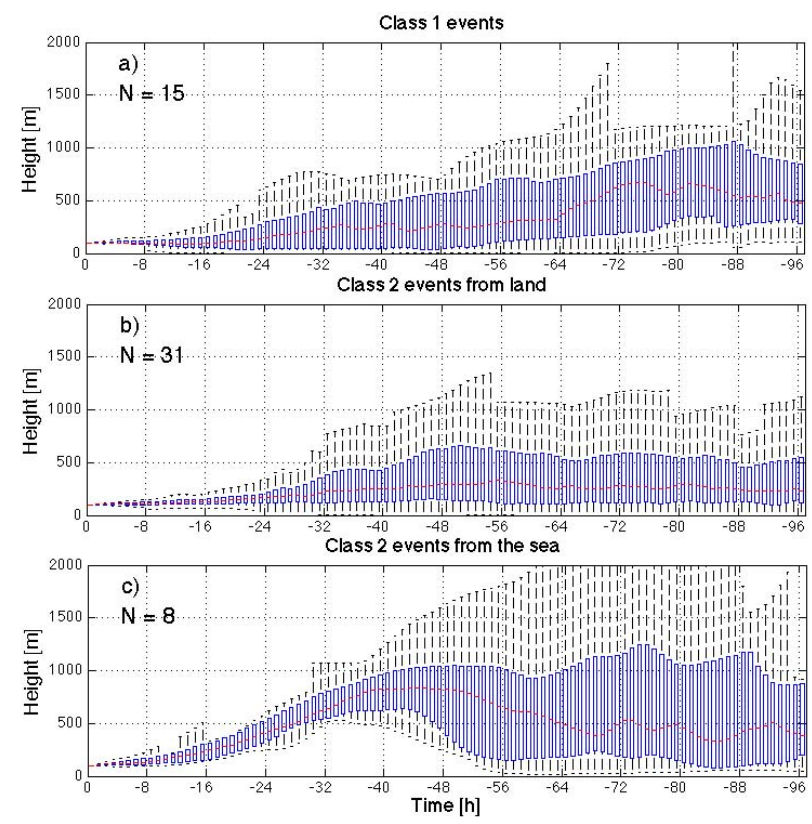

Fig. 13. Calculated 4-day back trajectories for class 1 events (a), class 2 events arriving from land (b) and class 2 events arriving from the sea (c). Time is hours to the past from the beginning of the event and height is in a.g.l. The red horizontal lines mark the median height, the edges of the blue boxes the 25 th and 75 th percentile and the black pillars the 5 th and 95 th percentile. The number $N$ indicates the number of trajectories used for statistics calculations. All the trajectories in (a), (b) and (c) are calculated to arrive at height $100 \mathrm{~m}$ a.g.1.

the presence of slowly growing events, for which a continuous particle growth was evident during several consecutive days.

Analyzing the new particle formation events and calculating growth rates was not straight forward. Our sizedistribution measurements started from $10 \mathrm{~nm}$, which means that the beginning of the nucleation was not detected. The median growth rate we determined for the class 1 events in the size range of 10 to $25 \mathrm{~nm}$, as well as the frequency of event days during the summer, was similar to that measured at coastal station Aboa (Asmi et al., 2010). This indicates that there is not a very significant difference in the growth rates between these two sites, which is somewhat surprising, considering that Aboa is close to the ocean that is the source of most condensable compounds in the region, whereas Dome $\mathrm{C}$ is high above the ocean and far away from the coast. In future, to better classify new particle formation events and calculate growth rates, it is crucial to be able to measure particle properties at sizes smaller than $10 \mathrm{~nm}$.

It is of interest to contrast the observed seasonal behavior of the aerosol number size distribution in Dome $\mathrm{C}$ to that reported for a high-latitude Arctic site, Ny-Ålesund in Svalbard (Tunved et al., 2013). At both sites, there is a relatively stable background particle population from late au- 
tumn until spring. In Ny-Ålesund this background is centered between about 100 and $200 \mathrm{~nm}$ of particle diameter, consisting mainly of long-range transported primary particles from anthropogenic sources. In Dome $\mathrm{C}$ the background is centered below $30 \mathrm{~nm}$, suggesting that these particles have been formed in the atmosphere before entering the continental Antarctica. At both sites, late spring and summer are characterized by active new particle formation with subsequent particle growth up to the sizes of cloud condensation nuclei (> 50-100 nm). In Ny-Ålesund this process starts when the anthropogenic background is still present, eventually replacing the background particles altogether during the summer. In air masses entering Dome $\mathrm{C}$, new particle formation and growth simply strengthen toward the summer, taking place more frequently close to the measurement site, and producing both more numerous and larger particles than in winter.

Acknowledgements. This research was supported by the Academy of Finland (Center of Excellence program, project number 127534, and Finnish Antarctic Research Program, decision nrs. 264375 and 264390), by the Nordic Top-level Research Initiative (TRI) Cryosphere-Atmosphere Interactions in a Changing Arctic Climate (CRAICC) and by the Italian "Programma Nazionale di Ricerche in Antartide" (PNRA) and developed as a sub-project 2010/A3.05 "Effetti radiativi diretti di aerosol e nubi sul clima alle alte latitudini: una prospettiva bipolare (DECA-POL)".

Meteorological data used in this study were obtained from the "RMO - Osservatorio Climatologico" of the Programma Nazionale di Ricerche in Antartide (PNRA) (http://www.climantartide.it).

Edited by: J. Bäck

\section{References}

Asmi, E., Frey, A., Virkkula, A., Ehn, M., Manninen, H. E., Timonen, H., Tolonen-Kivimäki, O., Aurela, M., Hillamo, R., and Kulmala, M.: Hygroscopicity and chemical composition of Antarctic sub-micrometre aerosol particles and observations of new particle formation, Atmos. Chem. Phys., 10, 4253-4271, doi:10.5194/acp-10-4253-2010, 2010.

Asmi, E., Kivekäs, N., Kerminen, V.-M., Komppula, M., Hyvärinen, A.-P., Hatakka, J., Viisanen, Y., and Lihavainen, H.: Secondary new particle formation in Northern Finland Pallas site between the years 2000 and 2010, Atmos. Chem. Phys., 11, 12959-12972, doi:10.5194/acp-11-12959-2011, 2011.

Becagli, S., Scarchilli, C., Traversi, R., Dayan, U., Severi, M., Frosini, D., Vitale, V., Mazzola, M., Lupi, A., Nava, S., and Udisti, R.: Study of present-day sources and transport processes affecting oxidised sulphu $r$ compounds in atmospheric aerosols at Dome C (Antarctica) from year-round sampling campaigns, Atmos. Environ., 52, 98-108, 2012.

Belosi, F., Contini, D., Donateo, A., Santachiara, G., and Prodi, F.: Aerosol size distribution at Nansen Ice Sheet Antarctica, Atmos. Res., 107, 42-50, 2012.

Busetto, M., Lanconelli, C., Mazzola, M., Lupi, A., Petkov, B., Vitale, V., Tomasi, C., Grigioni, P., and Pellegrini, A.: Parameteri- zation of clear sky effective emissivity under surface-based temperature inversion at Dome $\mathrm{C}$ and South Pole, Antarctica, Antarctic Science, Cambridge Univ Press, 1-14, 2013.

Charlson, R. J. and Wigley, T. M. L.: Sulphate aerosol and climatic change, Sci. Am., 270, 48-57, 1994.

Cosme, E., Hourdin, F., Genthon, C., and Martinerie, P.: Origin of dimethylsulfide, non-sea-salt sulfate, and methanesulfonic acid in eastern Antarctica, J. Geophys. Res., 110, D03302, doi:10.1029/2004JD004881, 2005.

Dal Maso, M., Kulmala, M., Riipinen, I., Wagner, R., Hussein, T., Aalto, P. P., and Lehtinen, K. E. J.: Formation and growth of fresh atmospheric aerosols: eight years of aerosol size distribution data from SMEAR II, Hyytiälä, Finland, Boreal Env. Res., 10, 323336, 2005.

Dal Maso, M., Sogacheva, L., Aalto, P. P., Riipinen, I., Komppula, M., Tunved, P., Korhonen, L., Suur-Uski, V., Hirsikko, A., Kurtén, T., Kerminen, V.-M., Lihavainen, H., Viisanen, Y., Hansson, H.-C., and Kulmala, M.: Aerosol size distribution measurements at four Nordic field stations: identification, analysis and trajectory analysis of new particle formation bursts, Tellus B, 59, 350-361, 2007.

Ehn, M., Vuollekoski, H., Petäjä, T., Kerminen, V.-M., Vana, M., Aalto, P. P., de Leeuw, G., Ceburnis, D., Dupuy, R., O'Dowd, C. D., and Kulmala, M.: Growth rates during coastal and marine new particle formation in western Ireland, J. Geophys. Res., 115, D18218, doi:10.1029/2010JD014292, 2010.

Fiebig, M., Lunder. C. R., and Stohl, A.: Tracing biomass burning aerosol from South America to Troll Research Station, Antarctica, Geophys. Res. Lett., 36, L14815, doi:10.1029/2009GL038531, 2009.

Forster, P., Ramaswamy, V., Artaxo, P., Berntsen, T., Betts, R., Fahey, D. W., Haywood, J., Lean, J., Lowe, D. C., Myhre, G., Nganga, J., Prinn, R., Raga, G., Schulz, M., and Van Dorland, R.: Cheanges in Atmospheric Constituents and in Radiative Forcing. In: Climate Change 2007: The Physical Science Basis. Contribution of Working Group I to the Fourth Assessment Report of the Intergovernmental Panel on Climate Change, edited by: S. Solomon, D. Qin, M. Manning, Z. Chen, M. Marquis, K. B. Averyt, M. Tignor and H. L. Miller, Cambridge University Press, Cambridge, United Kingdom and New York, NY, USA, 2007.

Genthon, C., Town, M. S., Six, D., Favier, V., Argentini, S., and Pellegrini, A.: Meteorological atmospheric boundary layer measurements and ECMWF analyses during summer at Dome C, Antarctica, J. Geophys. Res., 115, D05104, doi:10.1029/2009JD012741, 2010.

Ghan, S. J., Liu, X., Easter, R. C., Zaveri, R., Rasch, P. J., and Yoon, J.-H.: Toward a minimal representation of aerosols in climate models: Comparative decomposition of aerosol direct, semidirect, and indirect effects, J. Climate, 25, 6461-6476, 2012.

Gras, J. L.: Condensation nucleus size distribution at Mawson, Antarctica: Microphysics and chemistry, Atmos. Environ., 27, 1417-1425, 1993.

Hansen, G., Aspmo, K., Berg, T., Edvardsen, K., Fiebig, M., Kallenborn, R., Krognes, T., Lunder, C., Stebel, K., Schmidbauer, N., Solberg, S., and Yttri, K. E.: Atmospheric monitoring at the Norwegian Antarctic station Troll: measurement programme and first results, Polar Res., 28, 353-363, 2009.

Hara, K., Osada, K., Nishita-Hara, C., Yabuki, M., Hayashi, M., Yamanouchi, T., Wada, M., and Shiobara, M.: Seasonal features 
of ultrafine particle volatility in the coastal Antarctic troposphere, Atmos. Chem. Phys., 11, 9803-9812, doi:10.5194/acp-11-98032011, 2011.

Hirsikko, A., Laakso, L., Hõrrak, U., Aalto, P. P., Kerminen, V.-M., and Kulmala, M.: Annual and size dependent variation of growth rates and ion concentrations in boreal forest, Boreal Env. Res., 10, 357-369, 2005.

Hudson, S. R. and Brandt, R. E.: A Look at the Surface-Based Temperature Inversion on the Antarctic Plateau, J. Climate, 18, 16731696, 2005.

Hussein, T., Dal Maso, M., Petäjä, T., Koponen, I., Paatero, P., Aalto, P., Hämeri, K., and Kulmala M.: Evaluation of an automatic algorithm for fitting the particle number size distributions, Boreal Env. Res., 10, 337-355, 2005.

Ito, T.: Size distribution of Antarctic submicron aerosols, Tellus, 45B, 145-159, 1993.

James, I. N.: The Antarctic drainage flow: Implications for hemispheric flow on the Southern Hemisphere. Antarct. Sci., 1, 279 290. 1989.

Junninen, H., Hulkkonen, M., Riipinen, I., Nieminen, T., Hirsikko, A., Suni, T., Boy, M., Lee, S.-H., Vana, M., Tammet, H., Kerminen, V.-M., and Kulmala, M.: Observations on nocturnal growth of atmospheric clusters, Tellus B, 60, 365-371, 2008.

Kazil, J., Stier, P., Zhang, K., Quaas, J., Kinne, S., O’Donnell, D., Rast, S., Esch, M., Ferrachat, S., Lohmann, U., and Feichter, J.: Aerosol nucleation and its role for clouds and Earth's radiative forcing in the aerosol-climate model ECHAM5-HAM, Atmos. Chem. Phys., 10, 10733-10752, doi:10.5194/acp-1010733-2010, 2010.

Kerminen, V.-M., Petäjä, T., Manninen, H. E., Paasonen, P., Nieminen, T., Sipilä, M., Junninen, H., Ehn, M., Gagné, S., Laakso, L., Riipinen, I., Vehkamäki, H., Kurten, T., Ortega, I. K., Dal Maso, M., Brus, D., Hyvärinen, A., Lihavainen, H., Leppä, J., Lehtinen, K. E. J., Mirme, A., Mirme, S., Hõrrak, U., Berndt, T., Stratmann, F., Birmili, W., Wiedensohler, A., Metzger, A., Dommen, J., Baltensperger, U., Kiendler-Scharr, A., Mentel, T. F., Wildt, J., Winkler, P. M., Wagner, P. E., Petzold, A., Minikin, A., Plass-Dülmer, C., Pöschl, U., Laaksonen, A., and Kulmala, M.: Atmospheric nucleation: highlights of the EUCAARI project and future directions, Atmos. Chem. Phys., 10, 10829-10848, doi:10.5194/acp-10-10829-2010, 2010.

Koponen, I., Virkkula, A., Hillamo, R., Kerminen, V.-M., and Kulmala, M.: Number size distributions and concentrations of the continental summer aerosols in Queen Maud Land, Antarctica, J. Geophys. Res., 108, 4587, doi:10.1029/2003JD003614, 2003.

Kulmala, M., Vehkamäki, H., Petäjä, T., Dal Maso, M., Lauri, A., Kerminen, V.-M., Birmili, W., and McMurry P. H.: Formation and growth rates of ultrafine atmospheric particles: A review of observations, J. Aerosol Sci., 35, 143-176, 2004.

Kulmala, M., Lehtinen, K. E. J., and Laaksonen, A.: Cluster activation theory as an explanation of the linear dependence between formation rate of $3 \mathrm{~nm}$ particles and sulphuric acid concentration, Atmos. Chem. Phys., 6, 787-793, doi:10.5194/acp-6-787-2006, 2006.

Kulmala, M., Petäjä, T., Nieminen, T., Sipilä, M., Manninen, H. E., Lehtipalo, K., Dal Maso, M., Aalto, P. P., Junninen, H., Paasonen, P., Riipinen, I., Lehtinen, K. E. J., Laaksonen, A., and Kerminen, V.-M.: Measurement of the nucleation of atmospheric aerosol particles, Nat. Protoc., 7, 1651-1667, doi:10.1038/nprot.2012091, 2012.

Kyrö, E.-M., Kerminen, V.-M., Virkkula, A., Dal Maso, M., Parshintsev, J., Ruíz-Jimenez, J., Forsström, L., Manninen, H. E., Riekkola, M.-L., Heinonen, P., and Kulmala, M.: Antarctic new particle formation from continental biogenic precursors, Atmos. Chem. Phys., 13, 3527-3546, doi:10.5194/acp-13-3527-2013, 2013.

Makkonen, R., Asmi, A., Kerminen, V.-M., Boy, M., Arneth, A., Hari, P., and Kulmala, M.: Air pollution control and decreasing new particle formation lead to strong climate warming, Atmos. Chem. Phys., 12, 1515-1524, doi:10.5194/acp-12-15152012, 2012.

Manninen, H. E., Nieminen, T., Asmi, E., Gagné, S., Häkkinen, S., Lehtipalo, K., Aalto, P., Vana, M., Mirme, A., Mirme, S., Hõrrak, U., Plass-Dülmer, C., Stange, G., Kiss, G., Hoffer, A., Töro, N., Moerman, M., Henzing, B., de Leeuw, G., Brinkenberg, M., Kouvarakis, G. N., Bougiatioti, A., Mihalopoulos, N., O’Dowd, C., Ceburnis, D., Arneth, A., Svenningsson, B., Swietlicki, E., Tarozzi, L., Decesari, S., Facchini, M. C., Birmili, W., Sonntag, A., Wiedensohler, A., Boulon, J., Sellegri, K., Laj, P., Gysel, M., Bukowiecki, N., Weingartner, E., Wehrle, G., Laaksonen, A., Hamed, A., Joutsensaari, J., Petäjä, T., Kerminen, V.-M., and Kulmala, M.: EUCAARI ion spectrometer measurements at 12 European sites - analysis of new particle formation events, Atmos. Chem. Phys., 10, 7907-7927, doi:10.5194/acp-10-79072010, 2010.

Mauldin III, R., Eisele, F., Tanner, D., Kosciuch, E., Shetter, R., Lefer, B., Hall, S., Nowak, J., Buhr, M., Chen, G., Wang, P., and Davis, D.: Measurements of $\mathrm{OH}, \mathrm{H}_{2} \mathrm{SO}_{4}$, and MSA at the South Pole during ISCAT, Geophys. Res. Lett., 28, 3629-3632, 2001.

Mauldin, R. L., Kosciuch, E., Henry, B., Eisele, F., Shetter, R., Lefer, B., Chen, G., Davis, D., Bandy, A. and Thornton, D.: Measurements of $\mathrm{OH}, \mathrm{HO}_{2}+\mathrm{RO}_{2}, \mathrm{H}_{2} \mathrm{SO}_{4}$, and MSA at the South Pole during ISCAT 2000, Atmos. Environ., 38, 54235437, 2004.

Nieminen, T., Lehtinen, K. E. J., and Kulmala, M.: Sub-10 nm particle growth by vapor condensation - effects of vapor molecule size and particle thermal speed, Atmos. Chem. Phys., 10, 9773 9779, doi:10.5194/acp-10-9773-2010, 2010.

O’Dowd, C. D., Lowe, J. A., Smith, M. H., Davison, B., Hewitt, C. N., and Harrison, R. M.: Biogenic sulphur emissions and inferred non-sea-salt-sulphate cloud condensation nuclei in and around Antarctica, J. Geophys. Res., 102, 12839-12854, 1997.

Ortega, I. K., Suni, T., Boy, M., Grönholm, T., Manninen, H. E., Nieminen, T., Ehn, M., Junninen, H., Hakola, H., Hellén, H., Valmari, T., Arvela, H., Zegelin, S., Hughes, D., Kitchen, M., Cleugh, H., Worsnop, D. R., Kulmala, M., and Kerminen, V.-M.: New insights into nocturnal nucleation, Atmos. Chem. Phys., 12, 4297-4312, doi:10.5194/acp-12-4297-2012, 2012.

Park, J., Sakurai, H., Vollmers, K., and McMurry, P. H.: Aerosol size distributions measured at the South Pole during ISCAT, Atmos. Environ., 38, 5493-5500, 2004.

Pant, V., Siingh, D., and Kamra, A. K.: Size distribution of atmospheric aerosols at Maitri, Antarctica, Atmos. Environ., 45, 5138-5149, 2011

Petäjä, T., Mauldin, III, R. L., Kosciuch, E., McGrath, J., Nieminen, T., Paasonen, P., Boy, M., Adamov, A., Kotiaho, T., and Kulmala, M.: Sulfuric acid and $\mathrm{OH}$ concentrations in a boreal forest site, Atmos. Chem. Phys., 9, 7435-7448, doi:10.5194/acp- 
9-7435-2009, 2009.

Quaas, J., Ming, Y., Menon, S., Takemura, T., Wang, M., Penner, J. E., Gettelman, A., Lohmann, U., Bellouin, N., Boucher, O., Sayer, A. M., Thomas, G. E., McComiskey, A., Feingold, G., Hoose, C., Kristjánsson, J. E., Liu, X., Balkanski, Y., Donner, L. J., Ginoux, P. A., Stier, P., Grandey, B., Feichter, J., Sednev, I., Bauer, S. E., Koch, D., Grainger, R. G., Kirkevåg, A., Iversen, T., Seland, Ø., Easter, R., Ghan, S. J., Rasch, P. J., Morrison, H., Lamarque, J.-F., Iacono, M. J., Kinne, S., and Schulz, M.: Aerosol indirect effects - general circulation model intercomparison and evaluation with satellite data, Atmos. Chem. Phys., 9, 8697-8717, doi:10.5194/acp-9-8697-2009, 2009.

Riipinen, I., Pierce, J. R., Yli-Juuti, T., Nieminen, T., Häkkinen, S., Ehn, M., Junninen, H., Lehtipalo, K., Petäjä, T., Slowik, J., Chang, R., Shantz, N. C., Abbatt, J., Leaitch, W. R., Kerminen, V.-M., Worsnop, D. R., Pandis, S. N., Donahue, N. M., and Kulmala, M.: Organic condensation: a vital link connecting aerosol formation to cloud condensation nuclei (CCN) concentrations, Atmos. Chem. Phys., 11, 3865-3878, doi:10.5194/acp-11-38652011, 2011.

Samson, J. A. , Barnard, S. C., Obremski, J. S., Riley, D. C., Black, J. J., and Hogan, A. W.: On the systematic variation in surface aerosol concentration at the South Pole, Atmos. Res., 25, 385396, 1990 .

Shaw, G. E.: Antarctic aerosols: a review, Rev. Geophys., 26, 89112,1988

Sipilä, M., Berndt, T., Petäjä, T., Brus, D., Vanhanen, J., Stratmann, F., Petakoski, J., Mauldin, L., Hyvärinen, A.-P., Lihavainen, H., and Kulmala, M.: The Role of Sulphuric Acid in Atmospheric Nucleation, Science, 327, 1243-1246, 2010.

Suni, T., Kulmala, M., Hirsikko, A., Bergman, T., Laakso, L., Aalto, P. P., Leuning, R., Cleugh, H., Zegelin, S., Hughes, D., van Gorsel, E., Kitchen, M., Vana, M., Hõrrak, U., Mirme, S., Mirme, A., Sevanto, S., Twining, J., and Tadros, C.: Formation and characteristics of ions and charged aerosol particles in a native Australian Eucalypt forest, Atmos. Chem. Phys., 8, 129-139, doi:10.5194/acp-8-129-2008, 2008.

Tunved, P., Ström, J., and Krejci, R.: Arctic aerosol life cycle: linking aerosol size distributions observed between 2000 and 2010 with air mass transport and precipitation at Zeppelin station, Ny-Ålesund, Svalbard, Atmos. Chem. Phys., 13, 3643-3660, doi:10.5194/acp-13-3643-2013, 2013.
Udisti, R., Dayan, U., Becagli, S., Busetto, M., Frosini, D., Legrand, M., Lucarelli, F., Preunkert, S., Severi, M., Traversi, R., and Vitale, V.: Sea spray aerosol in central Antarctica. Present atmospheric behaviour and implications for paleoclimatic reconstructions, Atmos. Environ., 52, 109-120, 2012.

Vana, M., Ehn, M., Petäjä, T., Vuollekoski, H., Aalto, P., De Leeuw, G., Ceburnis, D., O’Dowd, C. D., and Kulmala, M.: Characteristic features of air ions at Mace Head on the west coast of Ireland, Atmos. Res., 90, 278-286, 2008.

Virkkula, A., Hirsikko, A., Vana, M., Aalto, P., Hillamo, R., and Kulmala M.: Charged particle size distribution and analysis of particle formation events at the Finnish Antarctic research station Alboa, Boreal Env. Res., 12, 397-408, 2007.

Wang, M. and Penner, J. E.: Aerosol indirect forcing in a global model with particle nucleation, Atmos. Chem. Phys., 9, 239-260, doi:10.5194/acp-9-239-2009, 2009.

Weller, R., Minikin, A., Wagenbach, D., and Dreiling, V.: Characterization of the inter-annual, seasonal, and diurnal variations of condensation particle concentrations at Neumayer, Antarctica, Atmos. Chem. Phys., 11, 13243-13257, doi:10.5194/acp11-13243-2011, 2011.

Winklmayr, W., Reischl, G. P., Lindner, A. O., and Berner, A.: New electromobility spectrometer for the measurement of aerosol size distributions in the size range from 1 to $1000 \mathrm{~nm}$, J. Aerosol Sci., 22, 289-296, 1991.

Yli-Juuti, T., Nieminen, T., Hirsikko, A., Aalto, P. P., Asmi, E., Hõrrak, U., Manninen, H. E., Patokoski, J., Dal Maso, M., Petäjä, T., Rinne, J., Kulmala, M., and Riipinen, I.: Growth rates of nucleation mode particles in Hyytiälä during 20032009: variation with particle size, season, data analysis method and ambient conditions, Atmos. Chem. Phys., 11, 12865-12886, doi:10.5194/acp-11-12865-2011, 2011.

Yu, F. and Luo, G.: Oceanic dimethyl sulfide emission and new particle formation around the coast of Antarctica: a modeling study of seasonal variations and comparison with measurements, Atmosphere, 1, 34-50, 2010. 